\title{
PENGARUH BRAND AWARENESS, PERCEIVED QUALITY DAN BRAND TRUST TERHADAP CUSTOMER LOYALTY PRODUK TOLAK ANGIN
}

\author{
Patricia Simon \\ Program Studi Magister Manajemen Universitas Tarumanagara \\ patcimon15@gmail.com \\ Miharni Tjokrosaputro \\ Program Studi Magister Manajemen Universitas Tarumanagara
}

\begin{abstract}
This research was attempted to explore what factors are contributing to customer loyalty of pharmaceutical and herbal product in Indonesia. Author used Tolak Angin brand as OTC drug model. Questionnaires method was used in this research. Data were analyzed using SPSS 24.0 by using data of 231 respondents who consumed any Tolak Angin products within 6 months. The result of the research shows that brand awareness and brand trust do partially have positive impact on customer loyalty. However, perceived quality partially doesn't have positive impact on customer loyalty. Furthermore, brand awareness, perceived quality and brand trust simultaneously do have positive impact on customer loyalty. The research provides insight to academics and pharmaceutical and traditional medicine company about how to manage customer loyalty of pharmaceutical and herbal product in Indonesia
\end{abstract}

Abstrak : Penelitian ini berusaha untuk mengeksplorasi faktor-faktor apa yang berkontribusi terhadap loyalitas pelanggan produk farmasi dan herbal di Indonesia. Penulis menggunakan merek Tolak Angin sebagai model obat bebas. Metode kuesioner digunakan dalam penelitian ini. Data dianalisis menggunakan SPSS 24.0 dengan menggunakan data 231 responden yang mengonsumsi produk Tolak Angin dalam waktu 6 bulan. Hasil penelitian menunjukkan bahwa kesadaran merek dan kepercayaan merek secara parsial berpengaruh positif terhadap loyalitas pelanggan. Namun, persepsi kualitas sebagian tidak memiliki dampak positif pada loyalitas pelanggan. Selain itu, kesadaran merek, persepsi kualitas, dan kepercayaan merek secara simultan berdampak positif terhadap loyalitas pelanggan. Penelitian ini memberikan wawasan kepada akademisi dan perusahaan farmasi dan obat tradisional tentang bagaimana mengelola loyalitas pelanggan terhadap produk farmasi dan herbal di Indonesia

Keywords : Customer loyalty, brand awareness, perceived quality, brand trust, pharmaceutical, herbal

\section{PENDAHULUAN \\ Latar Belakang}

Ketika mempunyai suatu keluhan penyakit, masyarakat Indonesia cenderung mencari jamu atau obat herbal yang sudah digunakan secara turun temurun dan terbukti efektif untuk mengatasi keluhan penyakit tersebut (local genius). Kecenderungan inilah yang membuat industri farmasi dan obat tradisional di Indonesia semakin berkembang. Persaingan menjadi semakin kompetitif, dimana terdapat banyak brand produk untuk suatu indikasi penyakit. Terkait dengan hal ini, maka penting untuk mengetahui faktor-faktor yang mempengaruhi customer loyalty pada produk farmasi dan obat tradisional. Diharapkan apabila tingkat loyalty tinggi terhadap suatu brand, maka customer tidak sensitif terhadap harga, akan melakukan pembelian ulang brand tersebut (bila dibutuhkan) dan tidak akan terjadi switching ke brand lain.

PT Sido Muncul adalah industri obat tradisional terbesar di Indonesia. Salah satu produk unggulan PT. Sido Muncul adalah Tolak Angin, Produk ini sudah menerima berbagai 
penghargaan seperti ICSA dan Top Brand produk herbal untuk produk masuk angin. Saat ini sudah terdapat beberapa produk kompetitor Tolak Angin, dimana kompetitor terberatnya adalah Antangin. Data penjualan selama tahun 2014-2016 menunjukan bahwa penjualan Tolak Angin fluktuatif, sementara penjualan Antangin bertumbuh sangat pesat. Di samping itu, top brand index Tolak Angin tahun 2016-2018 juga menunjukan trend menurun, sementara top brand index Antangin menunjukan trend meningkat.

\section{TINJAUAN PUSTAKA \& HIPOTESIS}

Oliver (1999) mendefinisikan customer loyalty adalah komitmen mendalam untuk melakukan pembelian ulang produk atau jasa secara konsisten pada masa yang akan datang, sehingga menyebabkan pembelian ulang brand yang sama atau pembelian brand set yang sama, terlepas dari pengaruh dan usaha tim pemasaran lain yang dapat menimbulkan brand switching. Pada tahap ultimate loyalty, customer akan berusaha mendapatkan brand tersebut meskipun menemui rintangan. Pada tahap ini customer bersedia untuk membayar harga berapapun untuk mendapatkan brand tersebut.

Brand awareness adalah kemampuan customer untuk recall dan recognize suatu brand, ditunjukkan pada kemampuannya untuk mengidentifikasi brand tersebut pada berbagai kondisi berbeda dan dapat menghubungkan nama brand, logo, simbol pada asosiasi tertentu dalam memori. Pada tingkat yang lebih tinggi dari tahap recall dan recognize, ada tahap top of mind, brand dominance, brand knowledge dan brand opinion (Fayrene \& Chai Lee, 2011). Customer membeli brand yang sudah dikenalnya dengan baik karena customer percaya terhadap brand tersebut. Customer merasa aman menggunakan brand yang sudah dikenalnya sehingga semakin besar peluang customer akan memilih dan membeli brand tersebut.

American Society for Quality dalam Kotler (2016) mendefinisikan quality adalah keseluruhan fitur dan karakteristik suatu produk atau jasa yang bergantung pada kemampuannya untuk memuaskan kebutuhan penggunanya. Vantamay (2007) mendefinisikan perceived quality adalah persepsi konsumen terhadap keseluruhan komponen produk, baik karakteristik tangible dan intangible. Menurut Sanyal \& Datta (2011), perceived quality dari suatu brand yang kuat menambah value pada saat konsumen menilai dan ingin melakukan pembelian suatu produk. Perceived quality dihasilkan pada saat memproses atribut produk sehingga konsumen dapat memutuskan kualitas produk tersebut. Perceived quality adalah salah satu komponen brand value, sehingga kualitas tinggi akan mendorong konsumen untuk memilih brand tersebut dibandingkan brand kompetitor.

Sahin, Zehir \& Kitapci et, al. (2011) mendefinisikan brand trust adalah kemauan konsumen untuk mengandalkan kemampuan brand tersebut dalam menunjukan performanya. Brand yang dapat dipercaya adalah brand yang secara konsisten menjaga janji dalam memberikan value bagi konsumen, mulai dari pada saat produk tersebut dikembangkan, diproduksi, dipasarkan dan diiklankan bahkan pada saat krisis terjadi. Trust penting untuk membangun hubungan yang kuat antara customer dan brand (Sahin, Zehir \& Kitapci, 2011).

Penelitian ini bertujuan untuk melihat faktor-faktor apa saja yang berpengaruh terhadap customer loyalty pada industri farmasi dan obat tradisional di Indonesia. Karena industri ini adalah industri yang kompetitif, maka industri farmasi perlu memberikan value lebih terhadap customer-nya supaya mempertahankan eksistensinya dan tetap bertumbuh. Variabel brand awareness, perceived quality dan brand trust diduga meningkatkan value bagi customer sehingga diharapkan bisa meningkatkan customer loyalty. Dengan demikian, hipotesis yang akan diuji dalam penelitian ini adalah sebagai berikut. 
H1 : Brand awareness secara parsial berpengaruh positif terhadap customer loyalty.

$\mathrm{H} 2$ : Perceived quality secara parsial berpengaruh positif terhadap customer loyalty.

H3 : Brand trust secara parsial berpengaruh positif terhadap customer loyalty.

$\mathrm{H} 4$ : Brand awareness, perceived quality dan brand trust secara simultan berpengaruh positif terhadap customer loyalty.

\section{METODE PENELITIAN}

Pengumpulan data dilakukan menggunakan kuesioner baik secara online (google form) maupun berupa formulir kepada responden yang sudah pernah minum produk Tolak Angin. Kuesioner disebar pada bulan April - Mei 2018. Kuesioner formulir disebarkan di area Universitas Tarumanagara dan di area Kembangan, Jakarta Barat. Data dari 231 responden diolah dengan SPSS version 24.0 for Windows.

Pengukuran variabel menggunakan skala Likert. Skala Likert mempunyai lima kategori, yaitu kategori 1 (sangat tidak setuju), kategori 2 (tidak setuju), kategori 3 (kurang setuju), kategori 4 (setuju) dan kategori 5 (sangat setuju). Kuesioner berisi 18 pernyataan yang mengukur 4 variabel. Pernyataan diadaptasi dari jurnal sebelumya (Dlacic \& Kezman, 2014; Panchal, Khan \& Ramesh, 2012; Sahin, Zehir \& Kitapci, 2011 dan Kiyani, 2012).

Setelah data terkumpul, selanjutnya penulis melakukan uji validitas dan reliabilitas pada masing-masing pernyataan. Setelah itu, penulis melakukan uji asumsi klasik karena data yang digunakan dalam model regresi berganda dalam menguji hipotesis harus memenuhi syarat uji asumsi klasik. Uji asumsi klasik mencakup uji multikolinearitas, uji heterokedastisitas dan uji normalitas.

Uji hipotesis dengan uji t untuk melihat pengaruh variabel independen secara parsial terhadap variabel dependen. Uji ANOVA dilakukan untuk melihat pengaruh variabel independen secara bersama-sama terhadap variabel dependen. Uji hipotesis dilakukan pada tingkat signifikansi 5\%. Apabila nilai $\mathrm{p}<0.05$ maka hipotesis diterima dan nilai $\mathrm{p}>0.05$ maka hipotesis ditolak (Priyastama, 2017). Selanjutnya penulis menghitung nilai $\mathrm{R}$ square untuk melihat berapa besar pengaruh ketiga variabel $\mathrm{X}$ tersebut terhadap variabel $\mathrm{Y}$.

\section{HASIL DAN DISKUSI}

\section{Hasil}

Berikut adalah hasil uji validitas \& reliabilitas dan tanggapan responden

Tabel 1. Hasil Uji Validitas \& Reliabilitas dan Tanggapan Responden

\begin{tabular}{|c|c|c|c|c|c|c|}
\hline Variabel & Indikator & $\begin{array}{l}\text { Corrected } \\
\text { item total } \\
\text { correlation }\end{array}$ & Hasil & $\begin{array}{l}\text { Cronbach } \\
\text { Alpha }\end{array}$ & Hasil & $\begin{array}{l}\text { Rata-rata } \\
\text { tanggapan } \\
\text { responden }\end{array}$ \\
\hline \multirow[t]{4}{*}{$\begin{array}{l}\text { Brand } \\
\text { awareness }\end{array}$} & $\begin{array}{l}\text { Saya dapat mengingat kemasan } \\
\text { produk Tolak Angin dengan } \\
\text { cepat. }\end{array}$ & 0.549 & Valid & 0.947 & Reliabel & 4.42 \\
\hline & $\begin{array}{l}\text { Saya dapat dengan mudah } \\
\text { mengenali produk Tolak Angin. }\end{array}$ & 0.525 & Valid & 0.947 & Reliabel & 4.42 \\
\hline & $\begin{array}{l}\text { Saya suka dengan tampilan } \\
\text { produk Tolak Angin. }\end{array}$ & 0.629 & Valid & 0.946 & Reliabel & 3.95 \\
\hline & Saya suka dengan logo produk & 0.588 & Valid & 0.947 & Reliabel & 3.83 \\
\hline
\end{tabular}




\begin{tabular}{|c|c|c|c|c|c|c|}
\hline & \multicolumn{6}{|l|}{ Tolak Angin. } \\
\hline & $\begin{array}{l}\text { Saya dapat dengan mudah } \\
\text { mengingat merk Tolak Angin. }\end{array}$ & 0.554 & Valid & 0.947 & Reliabel & 4.47 \\
\hline \multirow[t]{3}{*}{$\begin{array}{l}\text { Perceived } \\
\text { quality }\end{array}$} & $\begin{array}{l}\text { Produk Tolak Angin adalah } \\
\text { produk berkualitas terbaik bagi } \\
\text { saya. }\end{array}$ & 0.756 & Valid & 0.944 & Reliabel & 4.19 \\
\hline & $\begin{array}{l}\text { Saya yakin produk Tolak Angin } \\
\text { bekerja dengan baik. }\end{array}$ & 0.778 & Valid & 0.944 & Reliabel & 4.16 \\
\hline & $\begin{array}{l}\text { Kualitas produk Tolak Angin } \\
\text { sebanding dengan harganya. }\end{array}$ & 0.699 & Valid & 0.945 & Reliabel & 4.25 \\
\hline Variabel & Indikator & $\begin{array}{l}\text { Corrected } \\
\text { item total } \\
\text { correlation }\end{array}$ & Hasil & $\begin{array}{l}\text { Cronbach } \\
\text { Alpha }\end{array}$ & Hasil & $\begin{array}{l}\text { Rata-rata } \\
\text { tanggapan } \\
\text { responden }\end{array}$ \\
\hline \multirow[t]{5}{*}{$\begin{array}{l}\text { Brand } \\
\text { trust }\end{array}$} & $\begin{array}{l}\text { Saya yakin dengan produk Tolak } \\
\text { Angin. }\end{array}$ & 0.821 & Valid & 0.943 & Reliabel & 4.16 \\
\hline & $\begin{array}{l}\text { Produk Tolak Angin tidak pernah } \\
\text { mengecewakan saya. }\end{array}$ & 0.801 & Valid & 0.943 & Reliabel & 3.95 \\
\hline & $\begin{array}{l}\text { Produk Tolak Angin memenuhi } \\
\text { harapan saya. }\end{array}$ & 0.859 & Valid & 0.942 & Reliabel & 3.97 \\
\hline & $\begin{array}{l}\text { Produk Tolak Angin menjamin } \\
\text { kepuasan saya. }\end{array}$ & 0.870 & Valid & 0.941 & Reliabel & 3.93 \\
\hline & $\begin{array}{l}\text { Saya dapat mengandalkan produk } \\
\text { Tolak Angin untuk mengatasi } \\
\text { masalah saya. }\end{array}$ & 0.804 & Valid & 0.943 & Reliabel & 3.91 \\
\hline \multirow[t]{4}{*}{$\begin{array}{l}\text { Customer } \\
\text { loyalty }\end{array}$} & $\begin{array}{l}\text { Saya berniat akan selalu membeli } \\
\text { produk Tolak Angin. }\end{array}$ & 0.795 & Valid & 0.943 & Reliabel & 3.83 \\
\hline & $\begin{array}{l}\text { Saya akan tetap menggunakan } \\
\text { merk Tolak Angin. }\end{array}$ & 0.781 & Valid & 0.943 & Reliabel & 3.90 \\
\hline & $\begin{array}{l}\text { Saya akan menggunakan produk } \\
\text { lainnya dari produsen Tolak } \\
\text { Angin. }\end{array}$ & 0.230 & Valid & 0.955 & Reliabel & 3.23 \\
\hline & $\begin{array}{l}\text { Saya akan merekomendasikan } \\
\text { produk Tolak Angin kepada } \\
\text { orang lain. }\end{array}$ & 0.719 & Valid & 0.944 & Reliabel & 4.00 \\
\hline
\end{tabular}

Berdasarkan hasil pada tabel 1, model penelitian ini memenuhi syarat uji validitas dan reliabilitas. Syarat uji validitas adalah pernyataan valid apabila corrected item total correlation score $>0.196(0.196$ adalah nilai $r$ tabel pada $n=231$ dan $\alpha=0.05)$. Syarat uji reliabilitas adalah pertanyaan valid apabila nilai Cronbach alpha > 0.6 (Priyastama, 2017).

Selanjutnya, peneliti melakukan uji asumsi klasik yang terdiri dari uji multikolinearitas, uji heterokedastisitas dan uji normalitas.

Tabel 2. Hasil Uji Multikolinearitas

\begin{tabular}{|l|l|l|l|l|}
\hline No & Variabel & Tolerance & VIF & Hasil \\
\hline 1 & Brand Awareness & 0.549 & 1.820 & Tidak terdapat \\
& multikolinearitas. \\
\hline 3 & Perceived Quality & 0.257 & 3.889 & Brand Trust \\
\hline
\end{tabular}


Dari tabel di atas dapat dilihat bahwa nilai VIF lebih kecil dari 10 dan nilai tolerance lebih besar dari 0.1, maka dapat disimpulkan bahwa tidak terdapat gejala multikolinearitas dari model regresi tersebut (Priyastama, 2017).

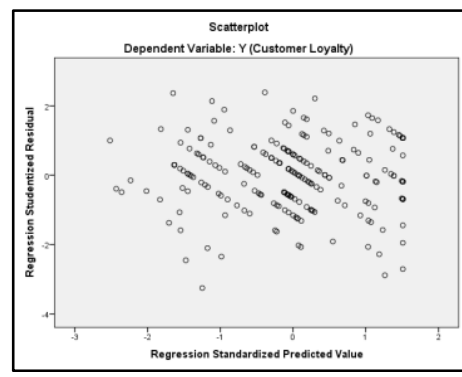

Gambar . Hasil Uji Heterokedastisitas

Berdasarkan grafik di atas dapat dilihat bahwa titik menyebar secara acak dan tidak memiliki pola tertentu. Titik juga menyebar di atas dan di bawah angka nol dari sumbu Y. Grafik di atas menunjukkan pada model penelitian ini tidak terjadi heterokedastisitas.

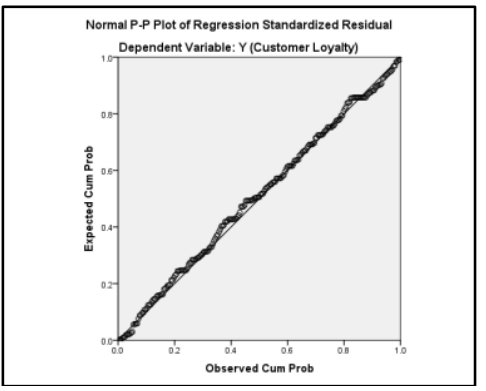

Gambar . Hasil Pengujian Normalitas

Berdasarkan uji normalitas melalui normal probability plot ( $p$-p plot) diketahui bahwa residual data menyebar di sekitar garis diagonal. Hal ini menggambarkan sebaran data terdistribusi secara normal dan memenuhi asumsi normalitas (Priyastama, 2017).

Tabel . Hasil Analisis Regresi Linear Berganda

\begin{tabular}{|c|c|c|c|}
\hline \multicolumn{2}{|c|}{ Model } & \multicolumn{2}{|c|}{ Unstandardized Coefficients } \\
\hline & & B & Std. Error \\
\hline \multirow[t]{4}{*}{1} & (Constant) & .347 & .210 \\
\hline & BA (Brand Awareness) & .166 & .062 \\
\hline & PQ (Perceived Quality) & .043 & .083 \\
\hline & BT (Brand Trust) & .637 & .074 \\
\hline
\end{tabular}

Berdasarkan tabel di atas dapat dirumuskan persamaan regresi sebagai berikut $\mathrm{CL}=0.347+$ $0.166 \mathrm{BA}+0.043 \mathrm{PQ}+0.637 \mathrm{BT}$.

Persamaan regresi di atas menunjukan :

- Nilai 0.347 merupakan konstanta yang menunjukkan tanpa adanya variabel BA, PQ dan BT nilai CL hanya sebesar 0.347

- Koefisen BA sebesar 0.166 yang menunjukkan kenaikan 1 satuan BA akan menyebabkan peningkatan CL sebesar 0.166.

- Koefisien PQ sebesar 0.043 yang menunjukkan kenaikan 1 satuan PQ akan menyebabkan peningkatan CL sebesar 0.043. 
- Koefisien BT sebesar 0.637 yang menunjukkan kenaikan 1 satuan BT akan menyebabkan peningkatan CL sebesar 0.637.

Tabel Nilai Signifikansi T parsial

\begin{tabular}{|l|l|r|r|r|}
\hline \multicolumn{2}{|l|}{ Model } & $\begin{array}{c}\text { Standardized } \\
\text { Coefficients }\end{array}$ & \multirow{2}{*}{ T } & Sig. \\
\cline { 3 - 5 } \multicolumn{2}{|l|}{} & \multicolumn{2}{|c|}{ Beta } & \\
\hline \multirow{3}{*}{1} & (Constant) & & 1.654 & .100 \\
\cline { 2 - 5 } & BA (Brand Awareness) & .142 & 2.664 & .008 \\
\cline { 2 - 5 } & PQ (Perceived Quality) & .040 & .512 & .609 \\
\cline { 2 - 5 } & BT (Brand Trust) & .671 & 8.618 & .000 \\
\hline
\end{tabular}

Dari tabel di atas, dapat dilihat bahwa untuk variabel brand awareness dan brand trust memiliki nilai t masing-masing sebesar 2.664 dan 8.618 serta nilai p sebesar 0.008 dan 0.000 . Nilai $\mathrm{t}$ hitung di atas nilai $\mathrm{t}$ tabel ( $\mathrm{t}$ tabel sebesar 1.960) dan nilai $\mathrm{p}$ di bawah 0.05 menunjukkan kedua variabel tersebut secara parsial berpengaruh positif dan signifikan terhadap customer loyalty. Variabel perceived quality memiliki nilai t dan nilai $\mathrm{p}$ masingmasing sebesar 0.512 dan 0.609 menunjukkan tidak ada pengaruh signifikan variabel ini secara parsial terhadap customer loyalty.

Tabel . Hasil Uji F (ANOVA)

\begin{tabular}{|c|c|c|c|c|c|c|}
\hline \multicolumn{7}{|c|}{ ANOVA $^{a}$} \\
\hline \multicolumn{2}{|c|}{ Model } & Sum of & Df & Mean & $\mathrm{F}$ & Sig. \\
\hline \multirow[t]{3}{*}{1} & Regression & 66.660 & 3 & 22.220 & 139.376 & $.000^{\mathrm{b}}$ \\
\hline & Residual & 36.189 & 227 & .159 & & \\
\hline & Total & 102.849 & 230 & & & \\
\hline \multicolumn{7}{|c|}{ a. Dependent Variable: Y (Customer Loyalty) } \\
\hline \multicolumn{7}{|c|}{$\begin{array}{l}\text { b. Predictors: (Constant), X3 (Brand Trust), X1 (Brand Awareness), X2 } \\
\text { (Perceived Quality) }\end{array}$} \\
\hline
\end{tabular}

Dari tabel di atas, dapat dilihat bahwa nilai p sebesar 0.000 menunjukan bahwa ketiga variabel secara simultan berpengaruh positif dan signifikan terhadap customer loyalty.

Hasil uji hipotesis dengan uji $\mathrm{t}$ dan uji $\mathrm{F}$ dirangkum dalam tabel di bawah ini.

Tabel . Hasil Uji Hipotesis

\begin{tabular}{|l|l|}
\hline & Hipotesis \\
\hline $\begin{array}{l}\text { H1 : Brand awareness secara parsial berpengaruh positif } \\
\text { terhadap customer loyalty. }\end{array}$ & Diterima \\
\hline $\begin{array}{l}\text { H2 : Perceived quality secara parsial berpengaruh positif } \\
\text { terhadap customer loyalty. }\end{array}$ & Ditolak \\
\hline $\begin{array}{l}\text { H3 : Brand trust secara parsial berpengaruh positif terhadap } \\
\text { customer loyalty. }\end{array}$ & Diterima \\
\hline $\begin{array}{l}\text { H4 : Brand awareness, perceived quality dan brand trust } \\
\text { secara simultan berpengaruh positif terhadap customer loyalty. }\end{array}$ & Diterima \\
\hline
\end{tabular}


Tabel 7. Hasil Pengujian R square $\left(\mathrm{R}^{2}\right)$

\begin{tabular}{|l|c|c|c|c|}
\hline \multicolumn{5}{|c|}{ Model Summary $^{\mathbf{b}}$} \\
\hline Model & $\mathrm{R}$ & $\mathrm{R}$ Square & $\begin{array}{c}\text { Adjusted R } \\
\text { Square }\end{array}$ & $\begin{array}{c}\text { Std. Error of the } \\
\text { Estimate }\end{array}$ \\
\hline 1 & $.805^{\mathrm{a}}$ & .648 & .643 & .3993 \\
\hline \multicolumn{5}{|l|}{ a. Predictors: (Constant), X1 (Brand Awareness), X2 (Perceived } \\
Quality), X3 (Brand Trust) \\
b. Dependent Variable: Y (Customer Loyalty) \\
\hline
\end{tabular}

Dari hasil di atas, dapat diketahui nilai $\mathrm{R}$ square dari model penelitian ini sebesar 0,648 yang berarti variabel brand awareness, perceived quality dan brand trust menyumbang sebesar $64,8 \%$ terhadap customer loyalty sedangkan sisanya $(100 \%-64,8 \%)=35,2 \%$ adalah variabel lain yang tidak termasuk ke dalam model ini (Priyastama, 2017).

\section{Diskusi}

Industri farmasi dan obat tradisional adalah industri yang kompetitif, dimana terdapat banyak brand untuk suatu jenis kegunaan obat. Dalam hal ini, supaya customer tidak mudah beralih ke brand lain, maka perlu adanya suatu customer loyalty yang tinggi. Tujuan penelitian ini adalah untuk melihat faktor-faktor apa saja yang dapat mempengaruhi customer loyalty terhadap suatu produk farmasi dan obat tradisional. Variabel independen dalam penelitian ini dibatasi hanya brand awareness, perceived quality dan brand trust. Penelitian ini diadaptasi dari penelitian sebelumnya Dlacic \& Kezman (2014) yang melakukan penelitian serupa pada produk farmasi di Kroasia.

Penelitian dilakukan dengan menyebarkan kuesioner kepada konsumen produk Tolak Angin di Jakarta secara online (google forms) ataupun dengan formulir dan sebanyak 231 respon dilanjutkan ke tahap analisa. Profil responden mayoritas adalah wanita berusia 20-30 tahun, pekerjaan sebagai karyawan swasta, pendidikan sarjana dan menggunakan produk Tolak Angin dalam 1 bulan terakhir.

Hasil analisis data validitas dan reliabilitas menunjukan bahwa semua variabel valid dan reliabel. Hasil uji asumsi klasik menunjukkan bahwa data terdistribusi normal dan tidak terdapat multikolinearitas \& heterokedastisitas.

Hasil uji hipotesis dengan uji t menunjukkan bahwa variabel X1 (brand awareness) secara parsial berpengaruh positif dan signifikan terhadap customer loyalty (H1 diterima). Hasil ini sama dengan penelitian Dlacic \& Kezman (2014) dan Khan (2012). Hal ini menunjukan PT. Sido Muncul dapat meningkatkan customer loyalty dengan meningkatkan awareness customer terhadap brand Tolak Angin.

Hasil uji hipotesis dengan uji t menunjukkan bahwa variabel X2 secara parsial tidak berpengaruh signifikan terhadap customer loyalty (H2 ditolak). Penelitian Marakanon \& Panjakajornsak (2017) di Thailand pada produk elektronik yang ramah lingkungan menunjukan bahwa tidak ada hubungan langsung antara variabel perceived quality dengan variabel customer loyalty. Variabel perceived quality mempunyai efek positif tidak langsung terhadap customer loyalty melalui variabel mediasi customer trust. Hasil serupa juga terlihat pada penelitian Kondasani \& Panda (2015) pada sektor pelayanan di rumah sakit swasta di India. Kondasani \& Panda meneliti hubungan antara perceived service quality, customer satisfaction terhadap customer loyalty. Hasil menunjukan bahwa tidak ada hubungan langsung antara perceived service quality dengan customer loyalty. Variabel perceived service quality mempunyai efek positif tidak langsung terhadap customer loyalty melalui variabel mediasi customer satisfaction.

Hasil penelitian Lei \& Jolibert (2012) juga sama dengan hasil penelitian ini. Lei \& Jolibert meneliti model mana yang paling sesuai untuk menggambarkan hubungan antara 
perceived quality, customer satisfaction dan customer loyalty intention pada rumah sakit di Cina. Hasil penelitian menunjukan bahwa model yang paling menggambarkan ketiga hubungan variabel itu adalah tidak ada pengaruh langsung antara perceived quality dan customer loyalty intention. Customer satisfaction memediasi hubungan antara perceived quality dan customer loyalty intention. Penelitian Lei \& Jolibert (2000) dan Kondasani \& Panda (2015) menunjukan kesamaan yaitu keduanya dilakukan pada sektor pelayanan kesehatan dan dilakukan di benua Asia.

Hasil uji hipotesis dengan uji t menunjukkan bahwa variabel X3 (brand trust) secara parsial mempunyai pengaruh positif dan signifikan terhadap customer loyalty (H3 diterima). Sesuai masukan pada penelitian Dlacic \& Kezman (2014), peneliti menggunakan jumlah pertanyaan lebih banyak untuk variabel X3. Hasilnya memperlihatkan ada pengaruh signifikan dan positif brand trust secara parsial terhadap customer loyalty. Pengaruh positif brand trust terhadap customer loyalty juga terlihat pada penelitian Kiyani, Niazi, Kizvi \& Khan (2012). Hal ini menunjukan PT. Sido Muncul dapat meningkatkan customer loyalty dengan membuat customer semakin percaya (trust) terhadap brand Tolak Angin.

Hasil uji ANOVA menunjukkan bahwa variabel brand awareness, perceived quality dan brand trust secara simultan berpengaruh positif dan signifikan terhadap customer loyalty (H4 diterima). Nilai R square dari model penelitian ini sebesar 0,648 yang berarti variabel brand awareness, perceived quality dan brand trust menyumbang sebesar 64,8\% terhadap customer loyalty sedangkan sisanya $(100 \%-64,8 \%)=35,2 \%$ adalah variabel lain yang tidak termasuk ke dalam model ini (Priyastama, 2017).

\section{KESIMPULAN DAN SARAN}

\section{Kesimpulan}

Berdasarkan hasil penelitian, dapat disimpulkan bahwa

- Variabel brand awareness mempunyai nilai T hitung (2.664) yang lebih besar dari T tabel (1.980) dan nilai $\mathrm{p}<0.05$. Dengan demikian, variabel brand awareness secara parsial memiliki pengaruh positif dan signifikan terhadap customer loyalty ( $\mathrm{H} 1$ diterima).

- Variabel perceived quality mempunyai nilai T hitung (0.512) yang lebih kecil dari T tabel (1.980) dan nilai $\mathrm{p}>0.05$. Dengan demikian, variabel perceived quality secara parsial tidak memiliki pengaruh signifikan terhadap customer loyalty (H2 ditolak).

- Variabel brand trust mempunyai nilai T hitung (8.618) yang lebih besar dari T tabel (1.980) dan nilai $\mathrm{p}<0.05$. Dengan demikian, variabel brand trust secara parsial memiliki pengaruh positif dan signifikan terhadap customer loyalty (H3 diterima).

- Variabel brand awareness, perceived quality dan brand trust mempunyai nilai $\mathrm{F}<$ 0.05 (nilai $\mathrm{F}=0.000$ ). Dengan demikian, variabel brand awareness, perceived quality dan brand trust secara bersama-sama memiliki pengaruh positif dan signifikan terhadap customer loyalty (H4 diterima).

\section{Implikasi managerial}

Peneliti menyarankan kepada PT. Sido Muncul untuk memperhatikan dan berfokus pada kegiatan untuk meningkatkan brand awareness dan brand trust Tolak Angin karena kedua variabel tersebut berpengaruh langsung terhadap customer loyalty. Brand trust memiliki pengaruh lebih besar terhadap customer loyalty daripada brand awareness. Hal ini terlihat dari koefisien regresi brand trust (X3) lebih besar daripada koefisien regresi brand awareness (X1)

Sebenarnya tabel 1 menunjukkan bahwa tingkat brand awareness customer Tolak Angin sudah tinggi (nilai rata-rata sebesar 4.218). Indikator "Saya dapat dengan mudah 
mengingat merk Tolak Angin" memiliki nilai rata-rata paling tinggi dibandingkan indikator lainnya (nilai rata-rata sebesar 4.47). Saran kepada PT. Sido Muncul untuk meningkatkan brand awareness yang bisa dilihat dari tanggapan hasil responden, yaitu perlu memperbaiki tampilan kemasan produk dan logo produk Tolak Angin. Kedua indikator ini mempunyai nilai rata-rata yang relatif lebih rendah dibandingkan indikator lain (nilai rata-rata untuk indikator "Saya suka dengan tampilan produk Tolak Angin" sebesar 3.95 dan nilai rata-rata untuk indikator "Saya suka dengan logo produk Tolak Angin" sebesar 3.83).

Saran kepada PT. Sido Muncul untuk meningkatkan brand trust bisa dilihat dari tanggapan hasil responden, yaitu masih ada konsumen yang gejala penyakitnya tidak teratasi dengan mengkonsumsi Tolak Angin. PT. Sido Muncul perlu melakukan inovasi terhadap produk Tolak Angin dengan membuat produk baru yang lebih ampuh untuk mengatasi gejala penyakit konsumen. Untuk selanjutnya, PT. Sido Muncul harus tetap menjaga kualitas produk Tolak Angin supaya konsumen tetap percaya (trust) terhadap Tolak Angin.

\section{Limitasi dan saran}

Limitasi dalam penelitian ini adalah hanya meneliti pengaruh variabel brand awareness, perceived quality dan brand trust terhadap customer loyalty. Peneliti menyarankan agar penelitian selanjutnya meneliti pengaruh variabel perceived quality terhadap customer loyalty menggunakan variabel mediasi customer satisfaction dan customer trust. Variabel mediasi ini mengacu ke penelitian yang dilakukan oleh Marakanon \& Panjakajornsak (2017), Lei \& Jolibert (2012) dan Kondasani \& Panda (2015).

Limitasi lainnya adalah penelitian ini hanya melibatkan responden yang tinggal di daerah Jakarta. Peneliti menyarankan agar penelitian berikutnya juga melibatkan jumlah responden yang lebih besar di area yang lebih luas agar hasilnya lebih dapat menunjukan hubungan antara variabel yang diteliti tersebut

\section{DAFTAR PUSTAKA}

Dlacic, Jasmina \& Kezman, Elvedina. (2014). Exploring Relationship Between Brand Equity and Customer Loyalty on Pharmaceutical Market. 16(2) 121-131.

Fayrene, Chieng \& Chai Lee, Goi. (2011). Customer-Based Brand Equity : A Literature Review. Journal of Arts Science \& Commerce. 11 (1) 33-42

IMS Health Indonesia. (2016). Data Indonesia Total Market Audit 2016. IMS Health Indonesia

Khan, Shahzad. (2012). Contribution of Brand Awareness and Brand Characteristics towards Customer Loyalty (A Study of Milk Industry of Peshawar Pakistan). 2(8) 170-176.

Kiyani, et.al (2012). The Relationship Between Brand Trust, Customer Satisfaction and Customer Loyalty. (Evidence from Automobile Sector of Pakistan). Interdisciplinary Journal of Contemporary Research in Business. 4 (1) 489-502

Kotler, Philip \& Keller, Kevin Lane. (2016). Marketing Management. USA : Pearson Education Inc

Priyastama, Romie. (2017). Buku Sakti Kuasai SPSS : Pengolahan Data \& Analisis Data. Yogyakarta : Start Up.

Sahin, Azize; Zehir, Cemal \& Kitapci, Hakan. (2011). The Effects of Brand Experiences, Trust and Satisfaction on Building Brand Loyalty : An Empirical Research on Global Brands. Procedia Social and Behavioral Sciences 24 1288-1301

Sanyal, Shamindra Nath \& Datta, Saroj Kumar. (2011). The Effect of Perceived Quality on Brand Equity an Empirical Study on Generic Drugs. Asia Pacific Journal of Marketing and Logistics, 23 (5) 604-625

Top Brand. (2016). Top Brand Index 2016 Fase 1. 
http://www.topbrand-award.com/topbrandsurvey/surveyresult/top_brand_index_2016_fase_1 Top Brand (2018). Top Brand Index 2018 Fase 1.

http://www.topbrand-award.com/topbrandsurvey/surveyresult/top_brand_index_2018_fase_1 Vantamay, Somphol. (2007). Understanding of Perceived Product Quality: Reviews and Recommendations, from http://www.bu.ac.th/knowledgecenter/epaper/jan_june2007/Somphol.pdf 


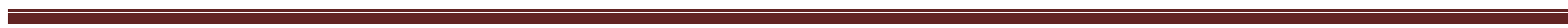
$\cdot$ 